\title{
TATAKRAMA BAHASA SUNDA DALAM KOMUNIKASI LISAN MASYARAKAT KAMPUNG JEMO KABUPATEN SUMEDANG
}

\author{
Sri Rizki Wulandari, Yayat Sudaryat, Hernawan \\ Jurusan Pendidikan Bahasa Daerah FPBS UPI \\ Pos-el: wsririzki@ymail.com, yayat.sudaryat@upi.edu,hernawan@upi.edu
}

\begin{abstract}
Abstrak
Latar belakang penelitian ini adalah untuk mengetahui dan mendeskripsikan tatakrama dalam komunikasi lisan masyarakat yang berada di Kampung Jémo, Desa Nagrak, Kecamatan Buahdua, Kabupaten Sumedang. Tujuan dari penelitian ini yaitu untuk mengetahui serta mendeskripsikan tatakrama bahasa Sunda, dalam komunikasi lisan masyarakat Kampung Jémo Desa Nagrak Buahdua Kabupaten Sumedang. Metode yang digunakan adalah metode deskriptif. Tehnik yang digunakan adalah tehnik observasi dan wawancara. Adapun instrumen yang digunakan adalah pedoman wawancara dengan dilengkapi alat perekam berupa ponsel. Hasilnya: (1) sebagian besar masyarakat Kampung Jémo mengetahui tentang tatakrama bahasa Sunda, tetapi tidak menggunakannya dalam percakapan sehari-hari; (2) kontéks situasi dalam pemakaian tatakrama bahasa Sunda, dilakukan dalam situasi santai dan formal. Jika diberi pertanyaan mengunakan bahasa Sunda, umumnya $(42,10 \%)$ menjawab menggunakan bahasa Sunda yang halus; dan (3) tahapan kata yang dipakai oleh masyarakat Kampung Jémo, lebih banyak menggunakan bahasa kasar $(41,1 \%)$. Hal ini menunjukan jika masyarakat mengetahui tatakrama bahasa Sunda, tetapi tidak digunakan dalam pembicaraan sehari-hari, dan lebih banyak menggunakan bahasa kasar.
\end{abstract}

Kata kunci: tatakrama basa, basa Sunda, komunikasi lisan

\section{THE ETIQUTTE OF SUNDANESE LANGUAGE IN SPOKEN LANGUAGE OF JEMO VILLAGERS IN NAGRAK VILLAGE SUMEDANG REGENCY}

\begin{abstract}
The background of this research is to know and describe the etiquette of the society live in Jemo village in Nagrak, the district of Buahdua in Sumedang regency, in spoken communication. The purpose of this research is to know and describe the etiquette of sundanese language in spoken language used by Jemo villagers in Nagrak, the village of Sumedang regency. This research paper uses descriptive method and the data were gained through observation and interview. The instrument of this research was in the form of interview that was recorded through cellular phone. The results are: (1) The majority of Jemo villagers know the etiquette of Sundanese language, but they do not use it in their daily conversation; (2) the context of Sundanese language etiquette is applied in the formal and informal situation. If they are asked by using Sundanese language, generally (42,10\%) they answer it in polite Sundanese language.; and (3) the word's phase used by jemo villagers are rude utterance. In the data analysis, there are $(41,1 \%)$ of the rude utterance spoken by them. So, the result shows that people know the etiquette of Sundanese language, but they do not apply it in their daily conversation, They tend to speak the rude utterance.
\end{abstract}

Keywords: tatakrama basa; Sundanese; oral communication

\section{PENDAHULUAN}

Bahasa mempunyai hubungan yang erat dengan manusia, sebab tumbuh kembangnya bahasa hanya ada dalam kehidupan manusisa. Manusia sulit untuk hidup jika tidak menggunakan bahasa, sebab bahasa merupakan alat dalam kehidupan manusia (Sudaryat, 2000, hlm. 9), utamanya untuk berkomunikasi. Banyak sekali bahasa yang dipakai manusia, tergantung tempat manusia itu tinggal. Salah satunya yaitu bahasa Sunda 
yang dipakai oleh orang Jawa Barat pada umumnya. Bahasa Sunda masih dipakai dan dipelihara oleh masyarakat penuturnya. Tercatat jika penutur bahasa Sunda paling banyak kedua setelah bahasa Jawa. Kedudukan bahasa Sunda merupakan nilai budaya, oleh karena itu terdapat tahapan dalam menggunakan bahasa Sunda. Dalam komunikasi bahasa Sunda, tahapan yang dimaksud yaitu tatakrama atau undak usuk bahasa Sunda (UUBS).

Undak usuk atau tatakrama bahasa merupakan tahapan dalam penggunaan bahasa Sunda yang secara umum terdiri dari ragam bahasa halus, sedang dan kasar. Ragam bahasa tersebut dipakai kepada orang yang dianggap lebih tinggi usia atau status sosialnya, lebih rendah, atau sepadan.

Sudaryat (2007, hlm. 294) mengungkapkan jika undak usuk atau tatakrama bahasa, merupakan sopan santun berbahasa dalam waktu berkomunikasi. Sopan santun tersebut menjadi sebuah nilai yang baik dalam bermasyarakat, serta ditunjukan untuk saling menghargai dan menghormati. Dalam hal ini, tatakrama berbahasa menjadi sebuah sistem dalam menggunakan ragam bahasa (hormat-tidak hormat), yang berkaitan dengan kekuasaan, kedudukan, keakraban, serta kontak di antara para penyaturnya termasuk orang yang diceritakan.

Dalam masyarakat kolonial-feodal orangSunda zaman dahulu, harkat dan derajat sosial hanya bisa memberi "nilai tambah" terhadap martabat manusia yang telah terlihat berbeda. Tapi di zaman sekarang, yang bisa disebut zaman demokrasi pancasila, terdapat pula tatakrama untuk memperlihatkan rasa saling menghormati dalam pergaulan antar sesama manusia. Dalam masarakat sekarang pun terdapat rasa saling menghormati untuk seseorang yang dianggap lebih tinggi, lebih rendah atau sepadan, serta atasan atau bawahan, tetapi berbeda dengan tatakrama di zaman kolonial feodal dahulu (Rosidi dkk., 2007, hlm. 9).

Saini K.M. (dalam Rosidi dkk., 2007, hlm. 9) memberi contoh pengalaman sehari-hari, seperti ini: "nu nulis (Saini K.M.) ngagunakeun basa lemes, boh dina pilihan kecap boh dina lentong. Ka Tukang nyemprot Hama...kuring ngagunakeun basa lemes tapi lentongna rada cohag, lantaran tukang kebon téh umurna saadieun nu nulis. Penulis "Saini K.M. menggunakan bahasa yang sopan, dalam pilihan kata ataupun intonasi. Kepada tukang yang bekerja menyemprot hama, dia menggunakan bahasa yang sopan teteapi dengan intonasi agak kasar, sebab tukang kebun tersebut umurnya lebih muda dari penulis."

Agar tidak terlalu luas dalam pembahasannya, penelitian ini dibatasi dalam kajian: 1) ragam bahasa hormat, sedang dan kasar; 2) konteks pemakaian tatakrama bahasa; serta 3) tahapan kata dalam pemakaian bahasa Sunda.

Sesuai dengan latar belakang serta rumusan masalah di atas, tujuan umum dari penelitian ini, untuk mengetahui serta mendeskripsikan tatakrama bahasa Sunda, dalam komunikasi lisan masyarakat Kampung Jémo, Desa Nagrak, Kec. Buahdua, Kabupaten Sumedang.

Di samping itu, penelitian ini mempunyai manfaat untuk masyarakat, dalam menambah pengetahuan mengenai tatakrama bahasa Sunda, meningkatkan kemampuan dalam menggunakan tatakrama bahasa Sunda, hususnya di Kampung Jémo Desa Nagrak.

\section{METODE}

Metode yang digunakan dalam penelitian ini, yaitu metode penelitian deskriptif yang menggambarkan atau memaparkan suatu hal, misalnya keadaan, kondisi, situasi, kejadian, dsb. Metode deskriptif merupakan metode yang mempunyai tujuan untuk mendeskripsikan atau menjelaskan kejadian yang berlangsung di masa sekarang (Sudjana, 2011, hlm. 52). 
Penelitian deskriptif hanya memaparkan apa yang nampak dan terjadi di lapangan. Data yang sudah terkumpul diklasifikasikan atau dikelompokan berdasarkan jenis, sifat dan kondisi (Arikunto, 2010, hlm. 3-4).

Langkah-langkah yang dilakukan dalam metode ini yaitu: mengadakan observasi di lingkungan masyarakat dengan cara ikut campur atau berpartisipasi dalam perkumpulan, untuk mendapatkan hasil rekaman secara diam-diam atau secara sadaprekam; mengadakan wawancara dengan masyarakat mengenai pengetahuannya terhadap tatakrama bahasa; menganalisis data dari hasil observasi dan wawancara. Sumber data dalam penelitian ini yaitu masyarakat Kampung Jémo, yang diwawancarai sebanyak 21 orang, sedangkan yang direkam secara tidak langsung sebanyak 14 orang. Desain penelitian yang digunakan, dibuat menggunakan bagan di bawah ini.

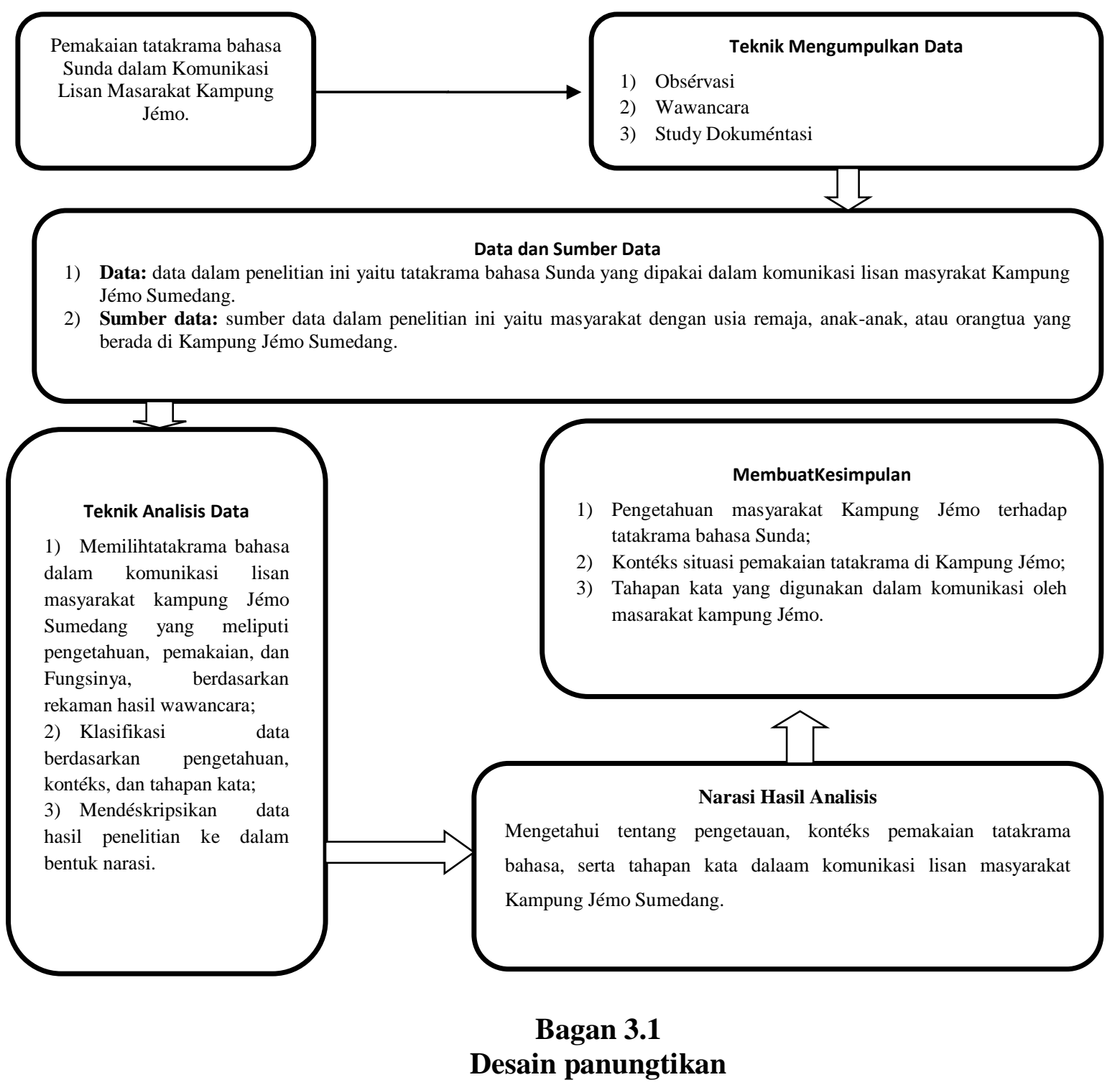

Teknik yang digunakan untuk mengumpulkan data, dalam penelitian ini yaitu teknik observasi dan wawancara. Teknik observasi dipakai jika penulis akan

mengamati tingkah laku penyatur dalam memakai bahasa. Teknik ini dilakukan dengan cara mengamati bahasa penyatur, baik dengan merekam ataupun mencatat 
(Sudaryat, 2000, hlm. 31). Teknik observasi dalam penelitian ini, dengan cara merekam pembicaraan penyatur tanpa sepengetahuan mereka, sedangkan teknik wawancara digunakan untuk mengetahui sejauh mana masyarakat mengetahui tatakrama bahasa Sunda.

Instrumen penelitian yaitu peralatan yang digunakan, untuk mengumpulkan data dalam proses penelitian. Instrumen yang mendukung dalam penelitian ini, yaitu pedoman wawancara, pedoman observasi, dan alat rekam yang berupa handphone.

Dalam tahap analisis, data diklasifikasikan berdasarkan kelompoknya, kegiatan ini dilakukan dengan proses analisis sebagai berikut: (1) memilih dan memilah tatakrama bahasa; (2) mengklasifikasi data berdasarkan pengetahuan, konteks situasi dan tahapan kata; (3) melakukan analisis data.

\section{HASIL DAN PEMBAHASAN}

Untuk mengungkapkan pengetahuan tentang tatakrama bahasa Sunda, diajukan pertanyaan: "Apa yang dimaksud dengan tatakrama bahasa Sunda?" terhadap pertanyaan tersebut, responden menjawab mengetahui. Dari 18 responden yang diberi pertanyaan, umumnya sebanyak 11 orang $(61,1 \%)$ menjawab mengetahui tatakrama bahasa Sunda, sedangkan responden yang banyaknya 7 orang $(39,9 \%)$ menjawab tidak mengetahui tatakrama bahasa Sunda.

Untuk mengungkapkan dipakai tidaknya tatakrama basa Sunda oleh masyarakat Kampung Jémo dibuat pertanyaan "Apakah tatakrama bahasa Sunda masih dipakai dalam obrolan seharihari?" terhadap pertanyaan tersebut,umumnya responden menjawab tidak menggunakan tatakrama bahasa Sunda.

Sedangkan alasannya karena tatakrama bahasa Sunda dipakai jika ada seseorang yang bertamu atau terhadap orang yang dianggap baru.

Masyarakat Kampung Jémo, seharihari menggunakan bahasa sedang dan bahasa kasar. Dari 19 responden yang diberi pertanyaan, umumnya sebanyak 8 orang $(42,1 \%)$ menjawab menggunakan tatakrama bahasa Sunda, sebanyak 3 orang $(15,8 \%)$ menjawab menggunakan bahasa kasar, sebanyak 3 orang $(15,8)$ menjawab menggunakan bahasa campuran, sebanyak 2 orang $(10,5 \%)$ menjawab tidak menggunakan bahasa Sunda, sedangkan 3 orang $(15,8 \%)$ tidak menjawab.

Untuk mengungkapkan, fungsi tatakrama bahasa Sunda dalam membedakan status sosial masyarakat Kampung Jémo, dibuat pertanyaan "Bagaimana fungsi tatakrama bahasa Sunda dalam membedakan status sosial masyarakat Kampung Jémo?" terhadap pertanyaan tersebut, umumnya responden menjawab adanya fungsi tatakrama bahasa Sunda dalam membedakan status sosial. Alasan yang digunakan sebab memberi penghormatan kepada orang yang dianggap mempunyai status lebih tinggi, misalnya lebih dari segi harta, pangkat dan derajat. Dari 9 responden yang diberi pertanyaan, umumnya sebanyak 8 orang $(88,9 \%)$ menjawab jika fungsi tatakrama bahasa Sunda ada dalam membedakan status sosia, sedangkan satu orang $(11,1 \%)$ menjawab tidak ada bedanya dalam membedakan status sosial.

Percakapan masyarakat dengan menggunakan tatakrama bahasa Sunda, bisa disimpulkan sebagai berikut:

1) Pertanyaan dengan bahasa sopan atau hormat - dijawab menggunakan bahasa sopan ada 16 orang $(80 \%)$

2) Pertanyaan dengan bahasa sopan atau hormat - dijawab menggunakan bahasa kasar ada 2 orang (10\%)

3) Pertanyaan dengan bahasa sopan atau hormat - dijawab menggunakan bahasa campuran (kasar dan hormat) ada 2 orang $(10 \%)$

Jika dilihat dari data di atas, bisa disimpulkan kalau masyarakat Kampung Jémo lebih banyak menggunakan bahasa yang sopan atau hormat, jika kita memberi pertanyaan dengan bahasa sopan juga. Hal ini memberi gamabaran kalau (80\%) 
masyarakat Kampung Jémo mengetahui tatakrama bahasa Sunda.

Berdasarkan analisis konteks pemakaian tatakrama bahasa Sunda, tatakrama bahasa Sunda dipakai dalam situasi santai (tidak formal) dalam kehipudan sehari-hari, begitu juga dalam situasi resmi (formal) jika bercerita dengan tamu. Bahasa Sunda yang umumnya dipakai sehari-hari dalam komunikasi di masyarakat Kampung Jémo, tergolong bahasa kasar, sedangkan bahasa Sunda yang dipakai jika ada tamu atau bertamu, tergolong bahasa yang sopan.

Latar dipakainya bahasa Sunda, baik bahasa Sopan maupun kasar, yaitu di rumah dan lingkungan masyarakat.

Dalam kehidupan sehari-hari, antara penyatur anak kecil, berbicara dengan anak kecil juga atau dengan orang tua, mereka menggunakan bahasa kasar. Tetapi, jika terhadap tamu atau seseorang yang mereka belum kenal, mereka menggunakan bahasa yang sopan. Hal ini terbukti dari hasil wawancara dengan menggunakan bahasa yang sopan, mereka menjawab dengan bahasa sopan kembali. Sebaliknya, jika ditanya dengan bahasa yang kasar, serta penyaturnya sudah akrab, mereka menjawab dengan bahasa yang kasar.

Ada pula kasus yang lain, jika anak kecil ditanya menggunakan bahasa Sunda, ada yang menjawab dengan menggunaka bahasa Sunda sopan, ada pula yang menjawab dengan menggunakan bahasa Indonesia.

Berdasarkan uraian di atas, terpapar jelaslah bahwa tindak tutur yang dipakai masyarakat Kampung Jémo, lebih banyak memakai bahasa kasar. Hal ini sesuai dengan data yang sudah dianalisis di bawah ini:

1) Tahapan kata bahasa sopan atau hormat $(33,9 \%)$

2) Tahapan kata bahasa kasar $(41,1 \%)$

3) Tahapan kata bahasa sedang $(21,3 \%)$

4) Tahapan kata bahasa campuran menggunakan bahasa Indonésia $(2,9 \%)$.

\section{SIMPULAN}

Hasil penelitian ini bisa disimpulkan, dalam beberapa hal di bawah ini:

a) masyarakat Kampung Jémo masih memakai bahasa Sunda, yang mengetahui tatakrama bahasanya. Mereka mempunyai pengetahuan terhadap tatakrama bahasa Sunda, sebab terlihat saat diwawancarai. Mereka memakai tatakrama bahasa Sunda sesuai dengan aturan pemakaiannya, kebanyakan $(61,1 \%)$ menjawab mengetahui tentang tatakrama bahasa Sunda;

b) konteks pemakaian tatakrama bahasa Sunda dalam situasi santai dan formal. Jika mereka ditanya menggunakan bahasa Sunda, umumnya $(42,10 \%)$; menjawab memakai bahasa Sunda lembut, sisanya menjawab memakai bahasa Sunda kasar $(15,8 \%)$; dan yang menjawab menggunakan bahasa campuran $(10,5 \%)$. Seterunya jawaban masyarakat kampung Jémo, tergantung kepada tatakrama bahasa Sunda yang digunakan oleh orang yang memberikan pertanyaan. Umumnya (80\%) jika diberi pertanyaan menggunakan bahasa yang sopan, mereka menjawab balik dengan bahasa sopan, sebagian kecil (10\%) jika ditanya dengan bahasa yang lembut, menggunakan bahasa kasar, serta sisanya (10\%) jika ditanya denganbahasa yang lembut, menjawab menggunakan bahasa campuran antara, lembut, kasar dan bahasa Indonesia;

c) tahapan kata yang dipakai masyarakat kampung Jémo, lebih banyak memakai kata kasar. Hal ini sesuai dengan hasil rekaman tanpa sepengetahuan masyarakat, yang sudah dilakukan analisinya yaitu kata kasar yang terdapat sebanyak $(41,1 \%)$, bahasa sopan/lembut $(33,9 \%)$, bahasa sedeng $(21,3 \%)$. Berdasarkan data tersebut terlihat jika tahapan kata yang banyak digunakan oleh masyarakat kampung Jémo, umumnya dalam pemakaiannya lebih banyak menggunakan bahasa kasar. 
PUSTAKA RUJUKAN

Arikunto, S. (2010). Prosedur Penelitian. Jakarta: PT. Asdi Mahasatya.

Rosidi, A. (2007). Polemik Undak Usuk Basa Sunda. Bandung: Kiblat

Sudaryat, Y. (2000). Elmuning Basa. Bandung: Walatra.

Sudaryat, Y. spk. (2007). Tata Basa Sunda Kiwari. Bandung: Yrama Widya.

Sudjana, N. (2011). Tuntunan Penulisan Karya Ilmiah. Bandung: Sinar Baru Algensindo.
Taufik. M. (2008). Korélasi Antara Pangaweruh jeung Kamampuh makéna Undak Usuk Basa Sunda Siswa Kelas X SMA Plus Merdéka soréang. Skripi Sarjana pada FPBS UPI Bandung: tidak diterbitkan.

\section{UCAPAN TERIMA KASIH}

Terima kasih kepada pengelola jurnal Lokabasa yang telah menerbitkan tulisan ini. Semoga tulisan ini ada manfaatnya bagi perkembangan ilmu pengetahuan. 